\title{
Sensitivity of Pseudomonas sp., from Ettawa Crossbreed Goat (PE) in Special Region of Yogyakarta (DIY) against antibiotic
}

\author{
Widodo Suwito ${ }^{1, *}$, Widagdo Sri Nugroho ${ }^{2}$ \\ ${ }^{1}$ Assessment Institutes for Agricultural Technology of Yogyakarta, Yogyakarta, 55584 \\ ${ }^{2}$ Faculty of Veterinary Medicine, Gadjah Mada University, Yogyakarta, 55281 \\ *Correspondence: widodo.suwito@yahoo.com
}

Received: November 27th 2019 ; Accepted: April 28 ${ }^{\text {th }}, 2020$; Published online: July $17^{\text {th }}, 2020$

\begin{abstract}
Abstrak
Tujuan: Pseudomonas sp., merupakan salah satu bakteri penyebab mastitis subklinis pada kambing peranakan Ettawa (PE) di Daerah Istimewa Yogyakarta (DIY). Mastitis subklinis pada kambing PE diatasi dengan pemberian antibiotika melalui intra mamae saat kering kandang atau seminggu sebelum diperah. Tujuan penelitian ini untuk mengetahui sensitifitas isolat Pseudomonas sp., asal mastitis subklinis pada kambing PE di DIY terhadap antibiotika yang digunakan di lapang.

Metode: Sebanyak 23 isolat Pseudomonas sp., dalam agar miring digunakan dalam penelitian ini. Semua isolat Pseudomonas sp., dalam agar miring ditanam dalam media Brain Heart Infusion (BHI) yang selanjutnya diidentifikasi secara biokimia ke arah Pseudomonas sp. Sensitifitas Pseudomonas sp., terhadap antibiotika dengan agar difusi menggunakan kertas cakram antibiotika yang sudah diketahui kosentrasinya.

Hasil: Hasil penelitian menunjukkan Kadar Hambat Minimal (KHM) isolat Pseudomonas sp., sensitif terhadap tetrasiklin, oksitetrasiklin, dan streptomisin, sedangkan sulfametoksazol resisten.

Kesimpulan: Mastitis subklinis pada kambing PE di DIY karena Pseudomonas sp., dapat diberikan tetrasiklin, oksitetrasiklin, dan streptomisin.
\end{abstract}

Kata Kunci: Kambing PE; Mastitis subklinis; Pseudomonas sp; Antibiotika

Abstract

Objective: Pseudomonas sp., is bacteria that subclinical mastitis cause in Ettawa crossbreed goat (PE) in special region of Yogyakarta (DIY). Subclinical mastitis in PE goat can be treated with antibiotic during dry period or one week after the milking. The aim of these study was to determined sensitivity Pseudomonas sp., isolate from PE goat subclinical mastitis in DIY against antibiotic that use in the field.

Methods: A total of 23 Pseudomonas sp., isolate on nutrient agar slope were used in this study. All Pseudomonas sp., isolate on nutrient agar slope were cultured in Brain Heart Infusion (BHI) medium and identified based on biochemical reaction. The sensitivity of Pseudomonas sp., isolate against antibiotic tested by diffusion agar with paper discs antibiotic with determine the concentration.

Results: Based on the Minimum Inhibition Concentration (MIC), the Pseudomonas sp., isolate was sensitive tetracycline, oxytetracycline, streptomycin, and resistant sulfamethoxazole. 
Conclusions: The PE goat subclinical mastitis disease in DIY which caused by Pseudomonas sp., can be treated with tetracycline, oxytetracycline, and streptomycin.

Keywords: Ettawa crossbreed goat; Subclinical mastitis; Pseudomonas sp; Antibiotic

\section{INTRODUCTION}

In PE goat, subclinical mastitis disease is loss financial effect in farmer PE goat because decrease the milk yield. The PE goat subclinical mastitis disease was no showed clinical symptom sign that can be observe the farmer PE goat. Conversely, in PE goat clinical mastitis disease showed clinical symptoms such as swollen the udder, heat, and pain when touched. All farmer PE goat in DIY was never know with sign of subclinical mastitis disease in PE goat. Subclinical mastitis in PE goat was only detected by California Mastitis Test (CMT). Characteristic of subclinical mastitis disease in goat was increased the Somatic Cell Count (SCC) in milk without accompanied symptom swollen the udder and the CMT test showed the coagulation [1]. Goat was called subclinical mastitis if CMT test showed positive $2(++)$ or $3(+++)$ [2].

Clinical and subclinical mastitis disease in PE goat mostly caused by bacteria infection. Pseudomonas sp., is Gram negative bacteria that causes subclinical mastitis disease in goat and sheep as much as $1.89 \%$ [3]. Pseudomonas sp., was reported that causes of PE goat subclinical mastitis disease in Sleman regency $18-22 \%$ [4]. The water which use wash the udder before milking was cause of Pseudomonas sp., clinical mastitis disease in PE goat at Sleman district because the water contaminated [5].

Currently, veterinary in DIY no treatment with antibiotic in PE goat subclinical mastitis. The veterinary was given antibiotic when sign PE goat clinical mastitis arise. Antibiotic treatment in PE goat subclinical mastitis disease less effective because it was causes residu in milk. Meanwhile, PE goat with subclinical mastitis disease the milk yield was still high, but along time milk yield was decrease until stop.

Subclinical mastitis disease in PE goat can be prevented with intra mamae antibiotic when dry period or one week after birth. It was never done at PE goat farmer in DIY. In addition, the habit PE goat farmer in DIY wash the udder before milking use raw water and it was causes Pseudomonas sp., clinical and subclinical mastitis disease. Commonly, subclinical mastitis in goat which caused by Pseudomonas sp., source from water which use wash the udder [7].

Treatment with antibiotic is drug of choice handling clinical and subclinical mastitis disease in PE goat. Administration of antibiotic in clinical and subclinical mastitis disease in PE goat can be successed if previously sensitivity test against antibiotic. Meanwhile, administration of antibiotic in clinical and subclinical mastitis disease in PE goat no done sensitivity tested against antibiotic previously because require a long time. Therefore, the aim of these study was to determined sensitivity Pseudomonas sp., isolate from PE goat subclinical mastitis in DIY against antibiotic that use in the field.

\section{MATERIALS AND METHODS}

\section{Research materials}

A total of 23 Pseudomonas sp., isolate from isolation and indentification PE goat subclinical mastitis based on biochemical reaction were collected on nutrient agar slope use in this study. Furthermore, antibiotic sensitivity used paper disc antibiotic such as streptomycin $10 \mu \mathrm{g}$, tetracycline $30 \mu \mathrm{g}$, oxytetracycline $30 \mu \mathrm{g}$, and sulfamethoxazole $1.25 \mu \mathrm{g}$.

\section{Re-identification Pseudomonas sp., isolate}

All Pseudomonas sp., isolate on nutrient agar slope re-identified of purity with culture in $25 \mathrm{ml}$ Brain Heart Infusion (BHI: CM 1135) (Oxoid Ltd., Basingstoke, United Kingdom) and incubation at $37^{\circ} \mathrm{C}$ for 24 hours. The next step, was cultured on Nutrient Agar (NA: CM 0003) (Oxoid Ltd., Basingstoke, United Kingdom) and incubation at $37^{\circ} \mathrm{C}$ for 24 hours. The separate colony with appear round, slippery, greenish was identified 
Pseudomonas sp., with Gram stain and biochemic reaction. Pseudomonas sp., colonoy on Nutrient Agar (NA: CM 0003) (Oxoid Ltd., Basingstoke, United Kingdom) and after incubation at $37^{\circ} \mathrm{C}$ for 24 hours were appear round, slippery and greenish [7].

\section{Sensitivity Pseudomonas sp., against antibiotic}

Sensitivity Pseudomonas $s p$. , against antibiotic was done by agar diffusion use paper disc antibiotic with determined the concentration. Minimum Inhibition Concentration (MIC) standard accorded from Clinical and Laboratory Standards Institute [8]. Briefly, Pseudomonas sp., isolate was cultured in Brain Heart Infusion medium (BHI: CM 1135) (Oxoid Ltd., Basingstoke, United Kingdom) and incubation at $37^{\circ} \mathrm{C}$ for 24 hours. The next step was cultured in Nutrient Agar (NA: CM 0003) (Oxoid Ltd., Basingstoke, United Kingdom) and incubation at $37^{\circ} \mathrm{C}$ for 24 hours. A separate Pseudomonas sp., colony was taken with steril Ose include in $\mathrm{NaCl}$ fisiologis solution and made cell suspension tantamount Mac (MC) Farland solution no 5. The MC Farland solution no 5 prepared by mix $0.5 \mathrm{ml} \mathrm{BaCl}_{2} 1 \%$ with $9.5 \mathrm{ml} \mathrm{H}_{2} \mathrm{SO}_{4} 1 \%$ solution. Concentration solution of MC Farland no 5 was equalent with bacteria content about $2 \times 10^{9} \mathrm{cfu} / \mathrm{ml}$ [8]. A total of $1 \mathrm{ml}$ cell suspension which equivalent solution MC Farland no 5 was dripped on the surface MÜeller Hinton Agar (MHA: CM 0337) (Oxoid Ltd., Basingstoke, United Kingdom). The next step, was flattend and dry in incubator for 10 minutes. The MÜeller Hinton Agar (MHA: CM 0337) (Oxoid Ltd., Basingstoke, United Kingdom) have been inoculated with Pseudomonas sp., then affixed with paper disc antibiotic and incubation at $37^{\circ} \mathrm{C}$ for 24 hours. Interpretation of antibiotic sensitivity was carried out based on diameter of inhibitory zone in milimeter (mm) [8].

\section{Statistical analyses}

Analyses data was carried out descriptively against the number of Pseudomonas sp., isolate group sensitive, intermediate, and resistant with antibiotic. The number of Pseudomonas sp., isolate group sensitive, intermediate, and resistant were converted to percentage and pie chart terms.

\section{RESULTS AND DISCUSSION}

Pseudomonas sp., which isolation from PE goat subclinical mastitis disease in DIY, with be store on nutrient agar slope still grew after culture in Brain Heart Infusion (BHI: CM 1135) (Oxoid Ltd., Basingstoke, United Kingdom) and incubation in $37^{\circ} \mathrm{C}$ for 24 hours. A total of 23 Pseudomonas sp., isolate on nutrient agar slope after identification all isolate show pure Gram negative, motil, rod

Tabel 1. Re-indentification of Pseudomonas sp., isolate from PE goat subclinical mastitis in DIY

\begin{tabular}{lll}
\hline No & Identification & Observation \\
\hline 1 & Colony in nutrient agar medium & \\
& colour & greenish \\
& shape & rounded, smooth \\
& Gram stain & \\
& Gram & negative \\
& shape & rod \\
& Enzyme & \\
& catalase & positive \\
& oxidase & positive \\
& Fermentation & \\
& lactose & negative \\
& glucose & negative \\
& sucrose & negative \\
\hline
\end{tabular}


shape, no spore, produce catalase and oxidase enzyme, no fermented lactose, glucose, and sucrose in $37^{\circ} \mathrm{C}$ for 24 hours were presented in Table 1.

Sensitivity of Pseudomonas sp., isolate against antibiotic based on diameter inhibition zone was presented in Table 2. Sensitivity Pseudomonas sp., isolate against antibiotic was grouped into 3 category such as sensitive, intermediate, and resistant. Pseudomonas sp., isolate called sensitive if diameter inhibition zone standard surpassed from CLSI. Intermediate group if diameter of the antibiotic inhibition zone was within a range predetermine standard from CLSI. Resistant group if diameter of the antibiotic inhibition zone was less than the predetermine standard from CLSI [8].

Total Pseudomonas sp., isolate from PE goat subclinical mastitis disease in DIY sensitive streptomycine $17 / 23 \quad(74 \%)$ was presented in Figure 1. This result showed that Pseudomonas sp., isolate has still high quite sensitive against streptomycine. Accordingly, streptomycine was still possible treatment subclinical mastitis PE goat in DIY. Meanwhile, based on information from Animal Health Center (PUSKESWAN) in DIY region, currently streptomycine is antibiotic that veterinary many still use in field and ussualy combine with penicillin. The purpose of combine antibiotic in order to be more

Tabel 1. Sensitivity of Pseudomonas sp., isolate from PE goat subclinical mastitis in DIY against antibiotic

\begin{tabular}{|c|c|c|c|c|c|}
\hline \multirow{2}{*}{ No } & \multirow{2}{*}{ Isolate code } & \multicolumn{4}{|c|}{ Zona inhibition $(\mathrm{mm})$} \\
\hline & & CTX $1.25 \mu \mathrm{g}$ & $\mathrm{S} 10 \mu \mathrm{g}$ & TE $30 \mu \mathrm{g}$ & OT $30 \mu \mathrm{g}$ \\
\hline 1 & S1 & 9 & $12^{\circ}$ & $20^{\circ}$ & $21^{\odot}$ \\
\hline 2 & S2 & $17^{\circ}$ & $8^{\prime}$ & $16^{\circ}$ & $17^{\circ}$ \\
\hline 3 & S3 & $7 \cdot$ & $12^{\odot}$ & $17^{\circ}$ & $20^{\circ}$ \\
\hline 4 & S4 & $18^{\odot}$ & $12^{\odot}$ & $7 \cdot$ & $7 \cdot$ \\
\hline 5 & M1 & $8^{\bullet}$ & $13^{\circ}$ & $18^{\circ}$ & $18^{\circ}$ \\
\hline 6 & K1 & $12^{\Delta}$ & $12^{\circ}$ & 9" & $18^{\odot}$ \\
\hline 7 & K2 & 9" & $11^{\circ}$ & $17^{\circ}$ & $19^{\circ}$ \\
\hline 8 & K3 & $17^{\circ}$ & $6^{\prime \prime}$ & $17^{\circ}$ & $17^{\circ}$ \\
\hline 9 & B1 & 9 & $11^{\circ}$ & $18^{\circ}$ & $19^{\circ}$ \\
\hline 10 & B2 & 17 & $13^{\circ}$ & $17^{\circ}$ & $21^{\odot}$ \\
\hline 11 & NG1 & $18^{\circ}$ & 9" & $13^{\Delta}$ & $17^{\circ}$ \\
\hline 12 & NG2 & $6^{-}$ & $13^{\circ}$ & $20^{\circ}$ & $21^{\odot}$ \\
\hline 13 & NG3 & $17^{\circ}$ & $12^{\circ}$ & $19^{\circ}$ & $21^{\odot}$ \\
\hline 14 & BT1 & 9" & $12^{\circ}$ & $16^{\odot}$ & $22^{\odot}$ \\
\hline 15 & BT2 & $12^{\Delta}$ & $13^{\circ}$ & $7 \cdot$ & $19^{\circ}$ \\
\hline 16 & KP1 & 7 & $12^{\odot}$ & $18^{\circ}$ & $21^{\odot}$ \\
\hline 17 & KP2 & $14^{\Delta}$ & $5^{\bullet}$ & $21^{\circ}$ & $21^{\odot}$ \\
\hline 18 & KP3 & $18^{\circ}$ & $13^{\circ}$ & 5" & $6=$ \\
\hline 19 & KP4 & 8 & $11^{\odot}$ & $19^{\circ}$ & $19^{\odot}$ \\
\hline 20 & SS1 & $6^{\prime \prime}$ & $11^{\circ}$ & $17^{\circ}$ & $19^{\circ}$ \\
\hline 21 & SS12 & $19^{\circ}$ & $12^{\circ}$ & $16^{\circ}$ & $19^{\circ}$ \\
\hline 22 & SP1 & $17^{\circ}$ & $12^{\Delta}$ & $19^{\circ}$ & $15^{\Delta}$ \\
\hline 23 & SP2 & 9" & 8" & $20^{\circ}$ & $21^{\circ}$ \\
\hline
\end{tabular}

a, resistant; $\Delta$, intermediate; $\odot$, sensitive; S, sensitive; I, intermediate; R, resistant; CTX $1.25 \mu \mathrm{g}$, Sulfamethoxazole (R:10 mm, I: 11-15 mm, S: $\geq 16 \mathrm{~mm}$ ); S $10 \mu \mathrm{g}$, Streptomycin (R:10 mm, I: 11-15 mm, S: $\geq 16 \mathrm{~mm}$ ); TE $30 \mu \mathrm{g}$, Tetracycline (R:10 mm, I: 11-15 $\mathrm{mm}, \mathrm{S}: \geq 16 \mathrm{~mm})$; OT $30 \mu \mathrm{g}$, Oxytetracycline (R:10 mm, I: 11-15 mm, S: $\geq 16 \mathrm{~mm}$ ) 
effective mechanism for Gram positive or negative infection bacteria. Combination penicillin and streptomycine were increased the sensitivity against Staphylococcus aureus until 75\% [9].

Streptomycin is an antibiotic with chemical structure of aminoglycosides which can suppress the bacterial growth. Mechanism of streptomycin is inhibiting permanently protein synthesis with bond ribosomes $30 \mathrm{~s}$ and $16 \mathrm{~s}$ subunits in the bacterial RNA section [10]. The bonding can be disrupted with the formation of amino acid code by mRNA, so that the order of amino acid in bacterial polypeptides were inappropriate. Incorrect of amino acid sequence lead caused formation of non-functional or toxic peptide chains in bacterial cells [10].

Sensitivity Pseudomonas sp., isolate from PE goat subclinical mastitis in DIY against tetracycline and oxytetracycline quite $74-87 \%$ high were presented in Figure 1. The high level of sensitivity Pseudomonas sp., isolate from PE goat subclinical mastitis in DIY against tetracycline and oxytetracycline may be still low application the antibiotics for PE goat clinical and subclinal mastitis case in DIY. Usually, clinical mastitis case in PE Goat was treatment with penicillin antibiotic group because often caused by Gram positive bacteria such as Staphylococcus sp., and Streptococcus $s p$. Clinical mastitis PE goat in DIY was caused by S. aureus as much as 55.5\% [11]. Staphylococcus sp., and Streptococcus sp., were primary cause clinical and subclinical mastitis in goat [12].

Tetracycline and oxytetracycline were broad spectrum antibiotics which use for infection Gram positive and negative bacteria with bacteriostatic effect. The mechanism of tetracycline is inhibiting protein synthesis at reversible bond at $30 \mathrm{~S}$ ribosomal receptor and tRNA-aminoacyl mRNA ribosome site complex receptor [13]. Currently, subclinical mastitis PE goat disease in DIY no given

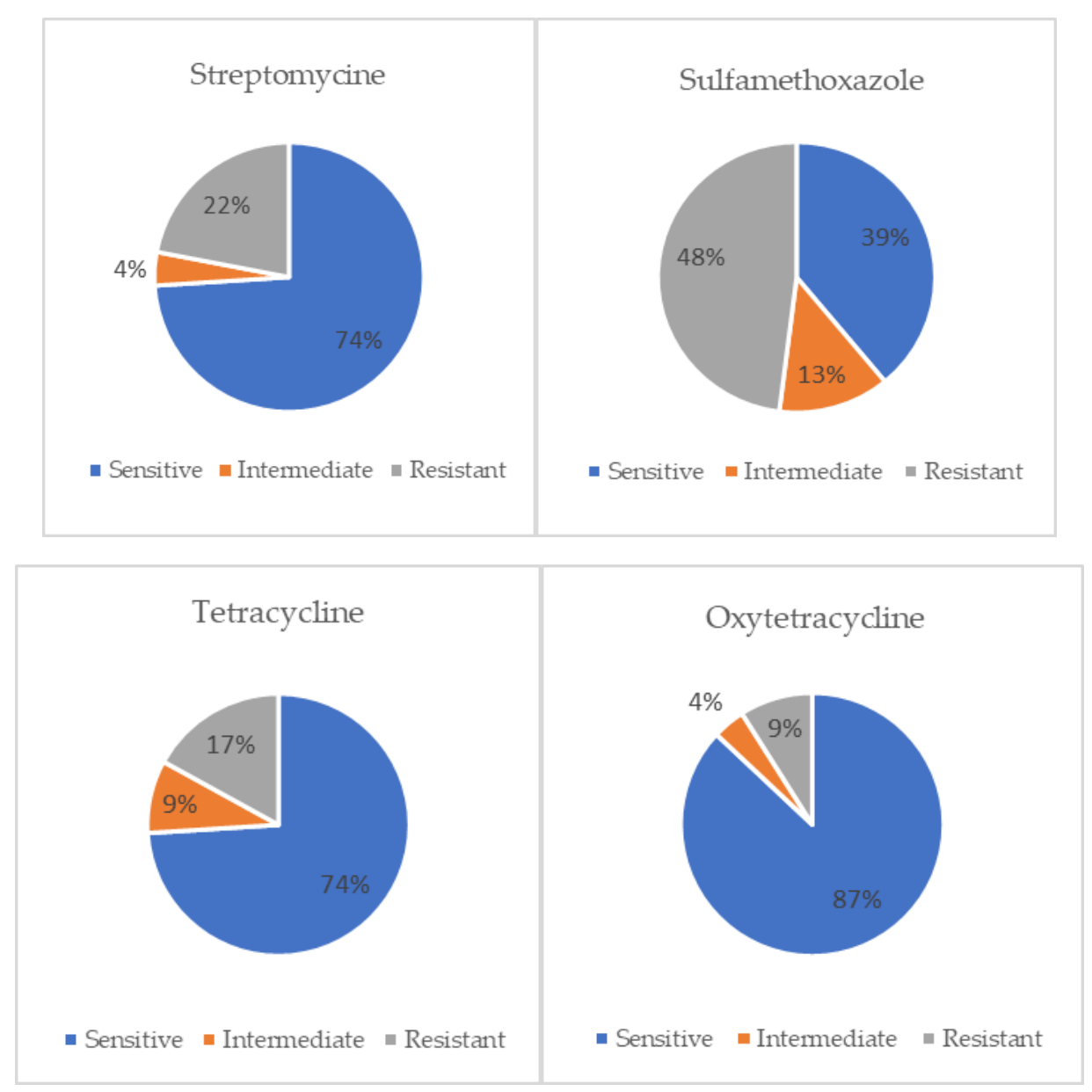

Figure 1. Sensitivity of Pseudomonas sp., isolate against antibiotic 
antibiotic because ineffective and inflict the antibiotics residue in milk although still high milk yield. The high of milk yield was risk factor subclinical mastitis in goat [14]. Subclinical mastitis in PE goat disease prevented by administration antibiotics intra mamae a week before birth and dry period. Administration antibiotics during dry period reduced subclinical mastitis infection [15]. Administration antibiotics during the dry period will be protect subclinical mastitis around $20 \%-60 \%$ more effective given in sheep than goat and clinical mastitis preventive need good management farm control [16].

Sensitivity Pseudomonas sp., isolate from PE goat subclinical mastitis disease in DIY region against sulfamethoxazole 9/23 (39\%) was presented in Figure 1. Sensitivity Pseudomonas sp., isolate from PE goat subclinical mastitis against sulfamethoxazole was lowest than streptomycin and tetracycline. These results showed that administration sulfamethoxazole in PE goat subclinical mastitis disease in DIY not recommended. The low level of sensitivity Pseudomonas sp., isolate against sulfamethoxazole not yet exactly knewn, but mutation may be suspected to be cause. The bacterial mutations in active side protein receptor that recognize antibiotics caused the sulfamethoxazole resistance [17]. Sulfamethoxazole is sulfa class antibiotic with broad spectrum so that use for infection caused by Gram positive and negative bacteria. Mechanism of sulfamethoxazole is inhibiting the folic acid synthesis and bacterial growth with inhibit dihydrofolic acid formation from para-aminobenzoic acid [18].

Pseudomonas sp., isolate which include in intermediate group for streptomycin 1/23 $(4 \%)$ sulfamethoxazole $3 / 23 \quad(13 \%)$, tetracycline $2 / 23(9 \%)$, and oxytetracycline $1 / 23(4 \%)$ were presented in Figure 1. Pseudomonas $s p$. isolate in groups intermediate was needed aware because over time it can become resistant due to genetic mutation. Mutation that occur in intermediate isolate bacterial tended slowly, so that codon bias occured which cause interference with tRNA movement [18]. Genetic mutation caused by environmental influences such as continuous administration antibiotic without regard the proper dosage. Antibiotic resistance occurred when use continuous antibiotic without regard the right dosage [19].

Total Pseudomonas sp., isolate from PE goat subclinical mastitis in DIY which resistant streptomycin 5/23 (22\%), sulfamethoxazole $11 / 23(48 \%)$, tetracycline $4 / 23(17 \%)$, oxytetracycline $2 / 23(9 \%)$ were presented in Figure 1. Cause of primary antibiotic resistant was definitely not yet known, but possibly due genetic mutation. In addition, genetic mutation caused by Pseudomonas sp., isolate which has resistance gene to antibiotic. The gene rpsL and rss that encode protein ribosomal at S12 and 16S RNA 22 and 23 were cause mycobacterium tuberculosis resistant to streptomycin [20,21]. Pseudomonas aeruginosa which caused clinical mastitis dairy goat in Italy was resistant to antibiotic beta-lactam and macrolide [22].

Pseudomonas sp., isolate resistant against tetracycline $9 \%$ and oxytetracycline $7 \%$ were presented in Figure 1. Pseudomonas sp., resistant against tetracycline and oxytetracycline were unknown surely. Some causes of tetracycline resistance such as the efflux pump failure by active transport protein pump, ribosome protect that produce proteins inhibit tetracycline aminoacyl tRNA bond, and inactivation enzymatic tetracycline [23]. Another, the enzyme that inhibit action of tetracycillin encoded by tet $x$ gene which associate with erm $F$ gene that methylase rRNA (5-7) encode [13].

Resistancy of Pseudomonas sp., isolate from PE goat subclinical mastitis disease in DIY against sulfamethoxazole $48 \%$ was presented in Figure 1. The resistance of Pseudomonas sp., isolate from PE goat subclinical mastitis against sulfamethoxazole was higher than streptomycin and tetracycline. The high of resistance Pseudomonas sp., isolate against sulfamethoxazole not yet knewn, even though veterinarian rarely give the antibiotic for PE goat clinical or subclinical mastitis. Therefore, resistance Pseudomonas sp., isolate against sulfamethoxazole possibly caused by the other factors. There were two mechanisms of 
sulfamethoxazole resistance namely intrinsic and obtainable [23]. Intrinsic resistance arisen when antibiotic not capable work in normal or higher dose. Obtainable resistance tended absolute if bacteria mutation found during the treatment and after treatment with antibiotic. Formation Dihydrofolate Synthetase (DHPS) and Dihydrofolate Reductase (DHFR) enzyme were caused form continue that folic acid and bacteria survive suspected cause of sulfamethoxazole resistance [23].

\section{CONCLUSIONS}

Pseudomonas sp., which isolated from PE goat subclinical mastitis in DIY sensitive against streptomycin, tetracycline, oxytetracycline, whereas sulfamethoxazole resistant.

\section{CONFLICT OF INTEREST}

The authors declare no real or perceived conflicts of interest.

\section{ACKNOWLEDGMENTS}

The authors are grateful to PE goat farmer in DIY and technicians in Microbiology and Veterinary Publih Pealth laboratory Gadjah Mada University for their assistance during the research.

\section{REFERENCES}

1. Marogna, G., C. Pilo, A. Vidili, S. Tola, G. Schianchiand, and S. G. Leori. 2012. Comparison of clinical findings, microbiological results, and farming parameters in goat herds affected by recurrent infectious mastitis. Small Ruminant Res. 102:74-83. doi:10.1016/j.smallrumres.2011.08.013.

2. Persson, Y. and I. Olofsson. 2011. Direct and indirect measurement of somatic cell count as indicator of intramammary infection in dairy goats. Acta. Vet. Scan. 53:1-5. doi:10.1186/1751-0147-53-15.

3. Abdalhamed, A. B., G. S. G. Zeedan, and H. A. A. A. Zeina. 2018. Isolation and identification of bacteria causing mastitis in small ruminants and their susceptibility to antibiotics, honey, essential oils, and plant extracts. Veterinary World. Mar; 11:355-362. doi:10.14202/vetworld.2018.355-362.

4. Suwito, W., Andriani, and W. S. Nugroho. 2019. Isolasi dan identifikasi bakteri dari susu kambing Peranakan Ettawa (PE) terjangkit mastitis subklinis di Kemiri Kebo, Sleman, Yogyakarta. J. Ilmu. Pet. 29:56-64.

5. Suwito, W., W. S. Nugroho, B. Sumiarto, and A. E. T. H. Wahyuni. 2014. Fakror-faktor risiko mastitis subklinis pada kambing peranakan Ettawah di kabupaten Sleman, Yogyakarta. J. Vet. 15:130-138.

6. Sela, S., O. Hammer-Muntz, R. Pinto, L. Weisblit, and G. Leitner. 2007. Phenotypic and genotypic characterization of Pseudomonas aeruginosa strains isolated from mastitis outbreaks in dairy herds. J. Dairy Res. 74:425-429. doi:10.1017/s0022029907002610.

7. Henry, D. and Speert, D. 2011. Pseudomonas. In: Versalovic J, Carroll K, Funke G, Jorgensen J, Landry M, Warnock D, editors. Man. of Clinic. Microbiol. 10th ed. ASM press, Washington, DC. p. 677-691.

8. CLSI (Clinical and Laboratory Standards Institute). 2012. performance standards for antimicrobial susceptibility testing. Twenty-Second Informational Supplement 32:70-78.

9. Ikiz, S., B. Basaran, E. B. Bingol, O. Cetin, G. Kasikci, N. Y. Ozgur, M. Ucmak, O. Yilmaz, M. C. Gunduz, and A. Sabuncu. 2013. Presence and antibiotic susceptibility patterns of contagious mastitis agents (Staphylococcus aureus and Streptococcus agalactiae) isolated from milks of dairy cows with subclinical mastitis. Turk. J. Vet. Anim. Sci. 37:569-574. doi:10.3906/vet-1302-63.

10. Demirci, H., F. Murphy, E. Murphy, T. Steven, Gregory, E. Albert, Dahlberg, and G. Jogl. 2013. A structural basis for streptomycin-induced misreading of the genetic code. Nat. Commun. 4:1355. doi:10.1038/ncomms2346.

11. Suwito, W., A. E. T. H. Wahyuni, W. S. Nugroho, and B. Sumiarto. 2013. Isolasi 
dan identifikasi bakteria mastitis klinis pada kambing peranakan Ettawah. Jurnal Sain Veteriner. 31:49-54.

12. Contreras, A., D. Sierra, A. Sanchez, J. C. Corrales, J. C. Marco, M. J. Paape, and C. Gonzalo. 2007. Mastitis in small ruminants. Small Ruminant Res. 68:145-153. doi: /10.1016/j.smallrumres.2006.09.011.

13. Sahasranaman, A., and J. L. WoolfordJr. 2013. in Encyclopedia of biological chemistry ( $2^{\text {nd }}$ ed). Academic Press, Cambridge, Massachusset. p. 116-121. doi:10.1016/B978-0-12-378630-2-00259-0.

14. Koop, G., C. A. Collar, N. Toft, M. Nielen, T. V. Werven, D. Bacon, and I. A. Gardner. 2013. Risk factors for subclinical intramammary infection in dairy goats in two longitudinal field studies evaluated by bayesian logistic regression. Prev. Vet. Med. 108:304-312. doi:10.1016/j.prevetmed.2012.11.007.

15. McDougal, S. and F. Anniss. 2005. Efficacy of antibiotic treatment at drying-off in curing existing infections and preventing new infections in dairy goats. In: Hogeveen, H. (Ed.), mastitis in dairy production. Academic Press, Wageningen. p. 523-528.

16. Petridis, I. G. and G. C. Fthenakis. 2014. Administration of antibiotics to ewes at the beginning of the dry-period. J. Dairy Res. 81:9-15. doi:10.1017/S0022029913000472.

17. Munita, J. M. and C. A. Arias. 2016. Mechanisms of Antibiotic Resistance. Microbiol. Spectr. 4:0016-2015. doi:10.1128/microbiolspec.VMBF-0016-201 5.

18. Villa, D. F., M. R. Aguilar, and L. Rojo. 2019. Folic Acid Antagonists: Antimicrobial and Immunomodulating Mechanisms and Applications. Int. J. Mol. Sci. 20:2-30. doi:10.3390/ijms20204996.

19. Indijah, S. W. and P. Fajri. 2016. Farmakologi. Modul bahan cetak ajar farmasi. Kementrian Kesehatan Republik Indonesia, Jakarta.

20. Tudó, G., E. Rey, S. Borrell, F. Alcaide, G. Codina, and P. Coll. 2010. Characterization of mutations in streptomycin-resistant Mycobacterium tuberculosis clinical isolates in the area of Barcelona. J. Antimicrob. Chemother. 65:2341-2346. doi:10.1093/jac/dkq322.

21. Ozturk, C. E., A. Sanic, D. Kaya, and I. Ceyhan. 2005. Molecular analysis of isoniazid, rifampin and streptomycin resistance in Mycobacterium tuberculosis isolates from patients with tuberculosis in Duzce, Turkey. Jpn. J. Infect. Dis. 58:309-312. doi:10.7883/yoken.JJID.2005.309.

22. Scaccabarozzi, L., L. Leoni, A. Ballarini, A. Barberio, C. Locatelli, A. Casula, V. Bronzo, G. Pisoni, O. Jousson, S. Morandi, L. Rapetti, A. García-Fernández, and P. Moroni. 2015. Pseudomonas aeruginosa in dairy goats: genotypic and phenotypic comparison of intramammary and environmental isolates. PloS One. 25:1-23. doi: 10.1371/journal.pone.0142973.

23. Todar, K. 2008. Bacterial resistance to antibiotics online. [internet]. Bacteriology. [cited 2014 Apr 1]. Available from: http://textbookbacteriology/resistanceanti microbial. 